
algal and plant diversity in aquatic and terrestrial ecosystems.

\title{
Knowledge for a different urban future: a reflection
}

\author{
Author \\ Erik Andersson

\section{Affiliation} \\ Stockholm Resilience Centre, \\ Stockholm University, Kräftriket \\ 2b, 10691 Stockholm, Sweden \& \\ Unit for Environmental Sciences \\ and Management, North-West \\ University, P.O. Box X6001, \\ Potchefstroom, 2520, North \\ West Province, Republic of \\ South Africa

\section{Corresponding Author \\ Erik Andersson \\ erik.andersson@su.se}

\section{Dates} \\ Published: 24 February 2021

\section{How to cite this article:} \\ Andersson, E., 2021, 'Knowledge \\ for a different urban future: \\ a reflection', Guest editorial, \\ Bothalia 51(1), a1. http://dx.doi. \\ org/10.38201/btha.abc.v51.i1.1
}

\section{Ecological infrastructure of urban regions}

What is the role of urban ecosystems and what do we need to know about it? Urban ecosystems jointly woven together into a green infrastructure are central to quality of life of urban residents and for mitigating the environmental impact of the increasingly global plurality known as 'cities'. Cities appropriate more and more of Earth's land surface, either for the built cities themselves (Seto et al. 2011) or for the production systems they need for their survival (e.g. Morgan \& Sonnino 2010; Nyström et al. 2019). However, 'cities' and 'urban' are somewhat deceptive terms as they may give the impression of homogeneous units with clear boundaries, which is very far from what they are - cities are characterised by small scale mixes of various land uses - from remnant nature and parks to transportation infrastructure, commercial areas and housing areas (from luxury homes to skyscrapers, and including informal settlements). Further blurring definitions, rural areas are in many ways becoming increasingly urban - people are moving back and forth between cities and the countryside and lifestyles are becoming increasingly similar through increasingly extensive and diffuse peri-urbanisation (e.g. Ravetz et al. 2013). For the most part, the urbanisation in Africa is following similar patterns as elsewhere in the world, but it becomes more distinct due to its extent and its rapid development (Anderson et al. 2013). One significant pattern is the anticipated rapid growth in smaller towns and the generally weak state control, the preponderance of feeble formal economic sectors, strong linkages between cities and rural areas through circular migration, urban remittances that contribute to rural economies, and rural districts where smaller towns expand and form connected 'urban' agglomerations (McHale et al. 2013).

Understanding the urbanisation context and positioning urban biodiversity work (research, restoration, conservation or design) as nested within a larger landscape will thus always be critically important. Quite often cities are located in biodiversity-rich areas (Seto et al. 2012) and promoting regionally embedded and connected urban ecosystems offers ways for - at least to some extent - mitigating habitat and biodiversity loss from urban expansion. It may also help to reduce the indirect impacts cities may have on the environmental quality of the surrounding landscape (e.g. Siebert et al. 2021). When located instead adjacent to homogeneous, intensively used production landscapes, cities and urban ecosystems may offer refugia for organisms that no longer are able to find sufficient habitat qualities in the urban hinterlands. Either way, larger scale connections between the city and its hinterlands are an essential aspect of urban ecology (as captured by urban gradient studies, see e.g. Du Toit et al. 
2020). They allow for more exchange and a more dynamic interplay that is important for the long-term development of the ecology of urban regions. Refugia and biodiversity-rich source areas within and outside the city support recolonisation and overall landscape functionality (Lundberg \& Moberg 2003). Cities with their global trade connections are also melting pots for novel combinations of biodiversity and may thus be sources of invasive species, which could potentially spread following the same routes (e.g. Hulme 2009). Flows are not limited to human mobility or the movement of other organisms, other geophysical processes reinforce the urban-rural linkages, as perhaps most evident in the flow of water and the many upstream-downstream issues that come with mixes of different land uses (e.g. Barnard et al. 2021).

Not only do cities grow outwards and interact with their surroundings, the urban environment itself is in constant change. Species meet and interact in new ways, forming novel and changeable urban assemblages (Hobbs et al. 2006; Kowarik 2011), climate change is exacerbated by the urban heat island effect, soils are constantly disturbed (Muller et al. 2021), green infrastructure is meshed with buildings and transportation infrastructure and water is rerouted and quite often polluted (Koekemoer et al. 2021). Land conversion and construction of transportation infrastructure or housing may be the most obvious land-use change, but people's actual use and stewardship of land (management practices, recreational uses, preferences for plants or other organisms etc.) will have additional, more subtle but still profound implications (Andersson et al. 2007). South Africa has a relatively long history of studying and documenting aspects of biodiversity and ecosystems through systematic biodiversity assessment (Cilliers et al. 2021). This has resulted in a knowledge base on biodiversity that continues to grow, the identification of linkages between land uses, priority areas and recommendations for biodiversity management and conservation (e.g. Kellner et al. 2021), and assessments of the status and trends of biodiversity as well as environmental quality (e.g. Berner et al. 2021; Muller et al. 2021, Shikwambaba et al. 2021, Siebert et al. 2021). Knowing the causes and likely consequences of change will become increasingly vital as we move into a future characterised by uncertainty and change. This knowledge is also a first step towards building resilience around liveable cities - for people as well as other species. The next step is to understand what it is that makes or could make (since we are not exactly in an ideal situation) them liveable.

Vegetation is the backbone of all urban ecosystems and an interface through which multiple different processes and actors connect. In addition to providing potential habitat for animals (humans included), plants are critically important for the quality and functional character of urban ecosystems. Photosynthesis and evapotranspiration generate biomass and various consumable resources, plants are actively involved in water and nutrient cycling, soil formation and water treatment. Vegetation plays a role in regulating local climate and in stabilising the system during extreme events (e.g. by reducing soil erosion) (e.g. El Kateb et al. 2013). These functions are also directly and indirectly important for our own wellbeing. Humanity is now primarily an urban species, but we are still dependent on the biosphere to provide us with multiple contributions to healthy, meaningful and fulfilling lives. An increasingly rich field describes the links between people and the biophysical world around us, exploring different ways of framing ecosystem services or nature's contributions to people, and thus better articulating and highlighting their role for our wellbeing. Beyond the baseline of our material needs and preferences, nature also contributes to spiritual wellbeing, creativity, sense making, place making and social and cultural life (e.g. Merçon et al. 2019), and exposure to urban ecosystems is for many the most frequent opportunity for realising these benefits. For example, gardens and gardening offer opportunities to, for example, project and reinforce identities, produce medicinal and nutritional products, and enhance aesthetic qualities (e.g. Cilliers et al. 2018). Remnants of less intensively or intentionally managed ecosystems offer opportunities to experience silence, a sense of non-human 'agency', wonder and real-world uncontrollability (e.g. Dixon 2002). These wellbeing outcomes are all grounded in functioning ecosystems, which in turn require healthy, diverse and resilient vegetation.

\section{Stewardship}

We need to recognise that people are fundamentally part of urban ecosystems and their resilience, in tangible as well as more abstract ways. Human activities exert pressure on ecosystems and biodiversity, but they are also an integral part of a co-evolutionary process that can be beneficial to urban ecosystems as well as people. Over the last 15 years, stewardship has gained attention as a way of analysing and describing local management, engagement and volunteerism for the sake of the larger environment as well as personal wellbeing, and general attitude and commitment towards the environment (Peçanha Enqvist et al. 2018; Chapin III 2020). Stewardship engagement may come from a need to act out or express care for the environment (e.g. Chawla 1998; Tidball \& Stedman 2013). Engaging with and for the urban environment can be a way to reclaim a bond that has been lost. Urbanisation has been highlighted as one of the drivers behind an increasing disconnect between people and the larger environment that we depend on (e.g. Miller 2005). An opportunity to participate and take on responsibility for something larger than yourself and your self-interest can also be 
empowering; it has been shown that people mobilise to increase their control over the local environment in a context where space is scarce and often contested (Ernstson et al. 2008). The South African Biodiversity Stewardship Programme is a formalised version of stewardship (led by conservation authorities entering into legal agreements with private and communal landowners) (Wright et al. 2018). Management is based on voluntary commitments from landowners, including those in and around urban areas (Holmes et al. 2012), with a range of different types of biodiversity stewardship agreements. However, as studies from around the world show, there are more ways people can be involved in management, decision making and learning about their daily environment (e.g. Wilson 2020). Not least, cities typically have a wide range of actors who influence the landscape in different ways. User interests, access to land and property rights are shared unequally among different groups, which influences their motivation, capacities and stewardship strategies (Colding \& Barthel 2013). For example, a comparison of people managing parks, cemeteries and allotment gardens in Stockholm showed that both ecological knowledge and commitment to management varied (Andersson et al. 2007). Urban residents can express a strong sense of care through their engagement in very localised stewardship activities such as gardening (Cilliers et al. 2018), urban foraging (Shackleton et al. 2017) and co-management initiatives (Graham \& Ernstson 2012; Colding \& Barthel 2013). Different interests are often associated with different capacities to influence governance processes (Baviskar 2003; Swyngedouw 2009). This raises concerns about the terms of participation, equal access and social justice, especially for cities.

\section{A language for learning}

One of the prerequisites for successful management and involvement in management - is knowledge. Urban ecological infrastructure can be an active space for learning. For example, gardens - community gardens, health clinic gardens, botanical gardens, home gardens - can be knowledge hubs and active interfaces for exchange and learning (Cilliers et al. 2018, 2021). They offer opportunities for peer-to-peer learning and transfer of skills as well as higher education. However, knowledge is often compartmentalised, and to combine knowledge from different sources can help make more systemic sense of different specific knowledge. One such bridge could be a different way of describing and discussing biodiversity. In times of change, and to connect ecology with human perceptions and needs, we need an expanded framework for investigating, communicating and sustainably making use of ecological properties. We need to know not only what species are and where they can be found, but what they do and how people perceive them and attribute meaning to them. There is a growing interest in functional traits as a bridge between ecophysiology, ecology and geosciences, and other disciplines more interested in human wellbeing, behaviour and sense making (Andersson et al. 2021). Traits which determine how organisms respond to change are a powerful tool for understanding some of the dimensions of ecological resilience (see e.g. Muller et al. 2021; Van Coller et al. 2021). When combined with traits describing the influence the organisms have on their environment, this approach can provide a baseline for starting to think about the resilience of the functions that in turn support ecosystem services.

\section{Roots of resilience for urban futures}

Human wellbeing will benefit from greener cities and urban areas that are designed with a careful eye to ecology. Not all direct contacts between people and a rich biodiversity are positive, not for people and certainly not for other organisms. However, this doesn't mean that we don't need, or cannot accommodate, organisms that we should not interact too closely with. Ecology has its own logic, and many of the processes we are dependent on are complex and will require more biodiversity than we may think, especially if they are to continue to work across different circumstances. Finding a balance in urban designs that supports both desired and necessary biodiversity requires deep knowledge, especially as some elements of a functional ecosystem may be dangerous to people. Universities and research institutes are not the only providers of such knowledge, but they are very important. As the articles in this special feature show, there is knowledge to build on, and knowledge that needs to be made available and actively translated into management action. To end with an alliteration: Knowledge, not least botanical knowledge, can and needs to inform restoration, reconciliation, reclamation, resilience, reconnection and risk reduction.

\section{Disclaimer}

The views expressed in the submitted article are the authors' own and not that of his institution. This paper has not been peer reviewed.

\section{Competing interests}

The authors declare that they have no financial or personal relationships that may have inappropriately influenced them in writing this article. 


\section{References}

Anderson, P.M.L., Okereke, C., Rudd, A. \& Parnell, S., 2013, 'Regional assessment of Africa', in T. Elmqvist, M. Fragkias, J. Goodness, B. Güneralp, P.J. Marcotullio, R.I. McDonald, S. Parnell, M. Schewenius, M. Sendstad, K.C. Seto \& C. Wilkinson (eds.), Urbanization, Biodiversity and Ecosystem Services: Challenges and Opportunities, pp. 453-459, Springer Netherlands, Cham.

Andersson, E., Barthel, S. \& Ahrné, K., 2007, 'Measuring social-ecological dynamics behind the generation of ecosystem services', Ecological Applications 17(5): 1267-1278, https://doi.org/10.1890/06-1116.1

Andersson, E., Haase, D., Anderson, P., Cortinovis, C., Goodness, J., Kendal, D., Lausch, A., McPhearson, T., Sikorska, D. \& Wellmann, T., 2021, in press, 'What are the traits of a social-ecological system: Towards a framework in support of urban sustainability', Urban Sustainability.

Barnard, S., Morgenthal, T.L., Stolz, M. \& Venter, A., 2021, 'Impact of land use and flow conditions on the phytoplankton of the Sabie River, South Africa', Bothalia 51(1): 75-92 (hardcopy); 1-18 (online) [this issue].

Baviskar, A., 2003, 'Between violence and desire: space, power, and identity in the making of metropolitan Delhi', International Social Science Journal 55(175): 89-98, https://doi.org/10.1111/issj.12184

Berner, J.M., Cloete, H. \& Shuuya, T., 2021, 'A baseline assessment of the photosynthetic potential of Welwitschia mirabilis using the JIP-test for monitoring and conservation purposes', Bothalia 51(1): 133-139 (hardcopy); 1-7 (online) [this issue].

Chapin III, F.S., 2020, Grassroots Stewardship: Sustainability within our reach, Oxford University Press, Oxford.

Chawla, L.,1998, 'Significant life experiences revisited: A review of research on sources of environmental sensitivity', The Journal of Environmental Education 29(3): 11-21, https://doi.org/10.1080/00958969809599114

Cilliers, S.S., Janse van Vuuren, S., Kellner, K., Krüger, G.H.J., Struwig, M., Van Niekerk, C.J.G. \& Siebert, S.J., 2021, 'Hundred years of Botany at the NWU: Contributions towards understanding plant and algae function, diversity and restoration in a changing environment', Bothalia 51(1): 7-21 (hardcopy); 1-7 (online) [this issue].

Cilliers, S.S., Siebert, S.J., Du Toit, M.J., Barthel, S., Mishra, S., Cornelius, S.F. \& Davoren, E., 2018, 'Garden ecosystem services of Sub-Saharan Africa and the role of health clinic gardens as social-ecological systems', Landscape and Urban Planning 180: 294-307, https://doi.org/10.1016/j. landurbplan.2017.01.011

Colding, J. \& Barthel, S., 2013, 'The potential of "Urban Green Commons" in the resilience building of cities', Ecological Economics 86: 156-166, https://doi.org/10.1016/j. ecolecon.2012.10.016

Dixon, T., 2002, City wilds: essays and stories about urban nature, University of Georgia Press, Athens.

Du Toit, M.J., Du Preez, C. \& Cilliers, S.S., 2021, 'Plant diversity and conservation value of wetlands along a rural-urban gradient', Bothalia 51(1): 45-62 (hardcopy); 1-18 (online) [this issue].

El Kateb, H., Zhang, H., Zhang, P. \& Mosandl, R., 2013, 'Soil erosion and surface runoff on different vegetation cov- ers and slope gradients: A field experiment in Southern Shaanxi Province, China', Catena 105: 1-10, https://doi. org/10.1016/j.catena.2012.12.012

Ernstson, H., Sörlin, S. \& Elmqvist, T., 2008, 'Social movements and ecosystem services - the role of social network structure in protecting and managing urban green areas in Stockholm', Ecology and Society 13(2): 39, https://doi. org/10.5751/ES-02589-130239

Graham, M. \& Ernstson, H., 2012, 'Comanagement at the fringes: examining stakeholder perspectives at Macassar Dunes, Cape Town, South Africa-at the intersection of high biodiversity, urban poverty, and inequality', Ecology and Society 17(3): 34, https://doi.org/10.5751/ES-04887-170334

Hobbs, R.J., Arico, S., Aronson, J., Baron, J.S., Bridgewater, P., Cramer, V.A., Epstein, P.R., Ewel, J.J., Klink, C.A., Lugo, A.E., Norton, D., Ojima, D., Richardson, D.M., Sanderson, E., W., Valladares, F., Vila, M., Zamora, R. \& Zobel, M., 2006, Novel ecosystems: theoretical and management aspects of the new ecological world order', Global Ecology and Biogeography 15(1): 1-7, https://doi.org/10.1111/ j.1466-822X.2006.00212.x

Holmes, P.M., Rebelo, A.G., Dorse, C. \& Wood, J., 2012, 'Can Cape Town's unique biodiversity be saved? Balancing conservation imperatives and development need', Ecology and Society 17(2): 28, https://doi.org/10.5751/ES-04552170228

Hulme, P.E., 2009, 'Trade, transport and trouble: managing invasive species pathways in an era of globalization', Journal of Applied Ecology 46(1): 10-18, https://doi. org/10.1111/j.1365-2664.2008.01600.x

Kellner, K., Mangani, R.T., Sebitloane, T.K., Chirima, G., Meyer, N., Coetzee, H.C., Malan, P. \& Koch, J., 2021, 'Restoration after bush control in selected rangeland areas of semi-arid savannas in south Africa', Bothalia 51(1): 93-105 (hardcopy); 1-13 (online) [this issue].

Koekemoer, L., Janse van Vuuren, S. \& Levanets, A., 2021, 'The influence of land use impacted tributaries on water quality and phytoplankton in the Mooi River, North West Province, South Africa', Bothalia 51(1): 23-44 (hardcopy); 1-22 (online) [this issue].

Kowarik, I., 2011, 'Novel urban ecosystems, biodiversity, and conservation', Environmental Pollution 159(8-9): 19741983, https://doi.org/10.1016/j.envpol.2011.02.022

Lundberg, J. \& Moberg, F., 2003, 'Mobile link organisms and ecosystem functioning: Implications for ecosystem resilience and management', Ecosystems 6(1): 87-98, https:// doi.org/10.1007/s10021-002-0150-4

McHale, M.R., Bunn, D.N., Pickett, S.T. \& Twine, W., 2013, 'Urban ecology in a developing world: why advanced socioecological theory needs Africa', Frontiers in Ecology and the Environment 11(10): 556-564, https://doi. org/10.1890/120157

Merçon, J., Vetter, S., Tengö, M., Cocks, M., Balvanera, P., Rosell, J.A. \& Ayala-Orozco, B., 2019, 'From local landscapes to international policy: contributions of the biocultural paradigm to global sustainability', Global Sustainability 2: e7, https://doi.org/10.1017/sus.2019.4

Miller, J.R., 2005, 'Biodiversity conservation and the extinction of experience', Trends in Ecology \& Evolution 20(8): 
430-434, https://doi.org/10.1016/j.tree.2005.05.013

Morgan, K. \& Sonnino, R., 2010, 'The urban foodscape: world cities and the new food equation', Cambridge Journal of Regions, Economy and Society 3(2): 209-224, https://doi.org/ 10.1093/cjres/rsq007

Muller, M., Siebert, S.J., Ntloko, B. \& Siebert, F., 2021, 'A floristic assessment of grassland diversity loss in South Africa', Bothalia 51(1): 147-155 (hardcopy); 1-9 (online) [this issue].

Nyström, M., Jouffray, J.-B.B., Norström, A.V., Crona, B., Søgaard Jørgensen, P., Carpenter, S.R., Bodin, Ö., Galaz, V. \& Folke, C., 2019, 'Anatomy and resilience of the global production ecosystem', Nature 575(7781): 98-108, https://doi.org/10.1038/s41586-019-1712-3

Peçanha Enqvist, J., West, S., Masterson, V.A., Haider, L.J., Svedin, U. \& Tengö, M., 2018, 'Stewardship as a boundary object for sustainability research: Linking care, knowledge and agency', Landscape and Urban Planning 179: 17-37, https://doi.org/10.1016/j.landurbplan.2018.07.005

Ravetz, J., Fertner, C. \& Nielsen, T.S., 2013, 'The dynamics of peri-urbanization', in K. Nilsson, S. Pauleit, S. Bell, C. Aalbers, Th.A. Sick Nielsen (eds.), Peri-Urban Futures: Scenarios and Models for Land use Change in Europe, pp. 13-44, Springer-Verlag, Berlin.

Seto, K.C., Fragkias, M., Güneralp, B. \& Reilly, M.K., 2011, 'A meta-analysis of global urban land expansion', PLoS ONE 6(8): e23777, https://doi.org/10.1371/journal. pone.0023777

Seto, K.C., Güneralp, B. \& Hutyra, L.R., 2012, 'Global forecasts of urban expansion to 2030 and direct impacts on biodiversity and carbon pools', Proceedings of the National Academy of Sciences 109(40): 16083-16088, https://doi. org/10.1073/pnas.1211658109

Shackleton, C., Hurley, P., Dahlberg, A., Emery, M. \& Nagendra, H., 2017, 'Urban foraging: A ubiquitous human practice overlooked by urban planners, policy, and research', Sustainability 9(10): 1884, https://doi.org/10.3390/ su9101884

Shikwambaba, P., Taylor, J.C., Govender, D. \& Botha. J., 2021, 'Diatom responses to river water quality in the Kruger National Park, South Africa', Bothalia 51(1): 63-74 (hardcopy); 1-11 (online) [this issue].

Siebert, F., Van Staden, N., Komape, D.M., Swemmer, A.M. \& Siebert, S.J., 2021, 'Effects of land-use change on herbaceous vegetation in a semi-arid Mopaneveld savanna', Bothalia 51(1): 107-132 (hardcopy); 1-26 (online) [this issue].

Swyngedouw, E., 2009, 'The antinomies of the postpolitical city: In search of a democratic politics of environmental production', International Journal of Urban and Regional Research 33(3): 601-620, https://doi.org/10.1111/j.14682427.2009.00859.x

Tidball, K., \& Stedman, R., 2013, 'Positive dependency and virtuous cycles: From resource dependence to resilience in urban social-ecological systems', Ecological Economics 86: 292-299, https://doi.org/10.1016/j.ecolecon.2012.10.004

Van Coller, H., Klem, J. \& Siebert, F., 2021, 'Drought tolerant forb flora of a semi-arid protected savanna in the Lowveld of South Africa', Bothalia 51(1): 141-146 (hardcopy); 1-6 (online) [this issue].

Wilson, N., Piers, L. \& Ratshikhopha, M., 2020, 'Land Reform and Biodiversity Stewardship 2020 Learning Exchange Proceedings Report', South African National Biodiversity Institute, Cape Town.

Wright, D.R., Stevens, C.M.D., Marnewick, D. \& Mortimer, G., 2018, 'Privately protected areas and biodiversity stewardship in South Africa: challenges and opportunities for implementation agencies', Parks 24: 45-62, https://doi. org/10.2305/IUCN.CH.2018.PARKS.24.2DRW.en 